\title{
Manuel Zapata y la Nación inclusiva ${ }^{24}$ Manuel Zapata and the Inclusive Nation
}

\author{
Alfonso Múnera \\ Recibido: 5 de Marzo 2011. Aprobado: 30 de Abril de 2011
}

\section{Resumen}

Las vivencias del escritor Manuel Zapata Olivella, sus escritos, su postura política en la defensa de lo nuestro, su actividad gestora en Letras nacionales, su concepción de raza e Identidad y su legado como maestro le ubican en un lugar de preponderancia en la literatura universal, anclado a procesos socioculturales y epistemológicos de vanguardia. El artículo presenta al escritor, y al conjunto de sus escritos, como uno de los más consistentes manifestantes nuestros, contra la colonialidad del poder y por la defensa del arte y la cultura colombianos.

Palabras clave: Manuel Zapata Olivella; Novela afrocolombiana; Letras nacionales.

\begin{abstract}
The experiences of the writer Manuel Zapata Olivella, his political stance in defense of our own, his management activity in Letras Nacionales, his perception of race and Identity, and his legacy as a teacher gives him a place of prominence in universal literature anchored to sociocultural and epistemological processes in vanguard. The article presents the writer, and the whole of his writings, as one of our most consistent protesters against the colonial power and the defense of Colombian art and culture.
\end{abstract}

Keywords: Manuel Zapata Olivella; Afrocolombian novel, Letras Nacionales.

Conocí a Manuel Zapata Olivella en 1965, el mismo año en el que comenzó una de sus tantas aventuras intelectuales, quijotescas y de consecuencias perdurables: la publicación de la revista Letras nacionales. Tenía yo entonces 12 años y con frecuencia permanecía horas en el amplio salón de las oficinas de los Correo Nacionales, que servía de depósito a las decenas de sacos repletos de libros y revistas chinos, soviéticos y de otros países que llegaban a Cartagena. Mi padre trabajaba allí, con un salario más bien modesto, y a pesar de ser "un liberal, algo conservador en política" como solía llamarlo Manuel, varios de sus mejores amigos de toda la vida se distinguieron por sus ideas y militancia de izquierda. En mi casa conocí, en parrandas amenizadas por Julio Machado, a Aumerle y a Reinerio de la

\footnotetext{
${ }^{24}$ Artículo derivado del proyecto de investigación Biblioteca Afrocolombiana, patrocinado por el Ministerio de Cultura de Colombia, del cual el autor hizo parte en la preparación, organización y estudio de los ensayos del escritor Manuel Zapata Olivella.
} 
Vega, a Carlos Cruz y a muchos otros que solían amanecer bajo el sonido triste de la dulzaina del ciego Machado cantándole a Goya y a los peloteros del mundial del 47.

Nunca vi a Manuel Zapata en las fiestas de la casa grande de Torices, y después supe que no era hombre de amanecidas de trago, que, por el contrario, le gustaba acostarse muy temprano para ponerse a trabajar apenas clareaba, tal y cual como lo hacen los campesinos. A este gran escritor y maestro de las letras lo recuerdo en la oficina de mi padre, discutiendo con él sobre la censura de prensa que obligaba al jefe de los correos a entregarle todo ese material revolucionario a la policía. Cosa que mi padre practicaba con gran elasticidad, ya que a sus espaldas y gracias a la complicidad de unos jóvenes trabajadores, que leían a Mao con devoción, llegaban a manos de sus amigos las revistas y los libros prohibidos. Y, quizás sin que a él lo asustara, a la de sus hijos.

En 1965 Manuel tenía ya 45 años de haber nacido en Lorica, Córdoba. Había vivido y estudiado en Cartagena hasta culminar el bachillerato, bajo la guía espiritual de su padre, el maestro y filósofo ateo, Antonio María Zapata. Había culminado sus estudios de Medicina, recorrido palmo a palmo la geografía nacional en afanosa búsqueda de sus tesoros culturales vivos, incluyendo los ríos remotos del pacífico, y viajado por Europa y Asia, hasta Rusia y China, dirigiendo una fantástica delegación del arte colombiano analfabeto y semianalfabeto, como el acostumbraba a llamarlo con clarísimo orgullo. Había antes suspendido sus estudios de medicina e impulsado por su "pasión vagamunda" caminado Centro América hasta llegar a México y los Estados Unidos. Había publicado varias de sus novelas, que lo consagraron como uno de los buenos de ese conjunto de escritores que estaban cambiando la literatura colombiana a unos niveles desconocidos, y se encontraba a punto de sacar al mercado el primer número de Letras nacionales.

\section{Los escritos de Manuel}

Manuel Zapata es uno de los escritores colombianos más leídos y traducidos en el exterior, después de García Márquez. Decenas de artículos sobre su obra se encuentran publicados en varias de las revistas más prestigiosas de crítica literaria de las universidades norteamericanas. Y en Colombia, el reconocimiento a su producción literaria y a su vasta e insuperable labor de estudioso y divulgador de nuestra cultura popular está destinado a crecer después de su muerte, hace apenas cinco años. Pero, sobre todo, lo que no hemos 
intentado a fondo todavía es la comprensión de sus dotes de ensayista. ${ }^{25} \mathrm{El}$ enorme valor para los pueblos del mundo de sus geniales intuiciones, de sus análisis premonitorios, de sus reflexiones y críticas tempranas al colonialismo cultural y de su radical defensa de lo que el englobó bajo el concepto de nacionalismo literario es asunto que se irá aclarando cada vez más en los próximos años.

Muchas de sus mejores ideas las escribió inicialmente en pequeños artículos en periódicos y revistas de toda índole y de diversa procedencia geográfica. Periódicos y revistas, muchos de ellos de poca circulación, conservados por el milagro de los buenos archiveros, que atestiguan, desde muy temprano, el objeto central de su pasión de escritor e investigador. No había terminado de llegar a Bogotá, a proseguir sus estudios universitarios, cuando ya está escribiendo párrafos amorosos sobre la cumbia y festejando a los anónimos artistas populares.

En nuestro medio, por desgracia, las antologías y compilaciones olvidan con frecuencia este material, al que catalogan de perecedero, y sólo por excepción se procede a su búsqueda y ordenamiento. Ya lo hizo Jacques Gilard con las notas de prensa de García Márquez y Jorge García con las de Héctor Rojas Herazo. Dos nombres que estuvieron muy cerca de la obra de Manuel. Lo que hemos seleccionado para este tomo no es propiamente una compilación indiscriminada de sus escritos de prensa. En nuestro caso hay un deliberado propósito que trasciende la simple acumulación cronológica de artículos: el hilo conductor, lo que le da sentido de unidad, a estos materiales es que constituyen el conjunto de escritos más consistente de escritor alguno nuestro contra la colonialidad del poder y por la defensa del arte y la cultura colombianos. ${ }^{26}$

Asombran las cosas que Manuel decía ya a mediados del siglo pasado, cuando García Márquez no había escrito todavía Cien Años de Soledad, y los hombres que se tenían por cultos en Colombia seguían creyendo que Marcos Fidel Suarez era nuestro mejor ejemplo de escritor y que las poesías a la patria de Miguel Antonio Caro tenían más valor que los

\footnotetext{
${ }^{25}$ En un artículo brillante y provocador, Lázaro Valdelamar, investigador del Instituto Internacional de Estudios de la Universidad de Cartagena, estudia la importancia del concepto "Muntu" en la obra ensayística y novelística de Manuel Zapata.

${ }^{26}$ Me refiero a la colonialidad entendida como "uno de los elementos constitutivos y específicos del patrón mundial de poder capitalista. Se funda en la imposición de una clasificación racial/étnica de la población del mundo como piedra angular de dicho patrón de poder y opera en cada uno de los planos, ámbitos y dimensiones materiales y subjetivas, de la existencia social cotidiana y a escala societal." Anibal Quijano, "Colonialidad del poder y clasificación social", Journal of world-systems research, VI, 2, Summer/Fall, 2000, p. 342. Manuel Zapata había entendido y expuesto con claridad desde los años sesenta del pasado siglo que la "raza" había sido desde los tiempos de la conquista un mecanismo central de dominación imperial.
} 
sonetos prosaicos del Tuerto López. En esos tiempos, en los que los cachacos confundían y habían enseñado al país a confundir la buena literatura con la buena gramática, Manuel les explicaba con convicción y entusiasmo el cambio radical que se estaba produciendo en las letras colombianas a manos de escritores de provincia, que se preciaban de todo menos de cultos, pero que tenían la gran virtud de unir a la lectura juiciosa de James Joice, Virginia Wolf, Marcel Proust y William Faulkner el aprendizaje atento de la realidad local, de sus personajes y de sus formas particulares del habla popular. Mucho antes de que García Márquez alcanzara sus éxitos deslumbrantes, Zapata Olivella se había convertido en uno de los más entusiastas defensores en Bogotá de esa nueva literatura e intuía su fuerza arrolladora.

De igual manera, nadie defendió mejor que él y ayudó a divulgar más allá de nuestras fronteras el arte y la cultura popular colombiana, tradicionalmente despreciados por los comentaristas cultos, pese a que ahora se habla mucho de su calidad e importancia para el progreso espiritual de la nación. Y lo hizo una y otra vez en congresos internacionales, como profesor invitado a universidades norteamericanas y europeas, y en esas columnas de prensa y artículos de revistas que escribía al mismo tiempo que organizaba festivales y encuentros o visitaba pueblos alejados para escuchar a una cantadora negra.

He dividido el material un poco arbitrariamente en tres partes: en la primera he seleccionado sus trabajos anteriores a Letras nacionales, sobre temas relativos al folclor nacional, la literatura, la política o los problemas sociales. Cubre un período que va de 1940 a 1965. En la segunda, he escogido una muestra de los editoriales que aparecieron firmados por él en Letras nacionales, en los que trabajó de manera consistente sus reflexiones sobre el colonialismo cultural, sobre el racismo y la discriminación, sobre la cultura de los analfabetos y semianalfabetos y sobre el nacionalismo literario. Corpus teórico de los más audaces y avanzados de la nación en los años sesenta y setenta del pasado siglo. Los ensayos y artículos de prensa de Manuel Zapata dialogaban con los que en otros lugares del mundo escribían Aimé Césaire, Leopoldo Sangor y Edouard Glissant. Y es quizás el único de nuestros pensadores que a mediados del siglo XX piensa a la nación como un todo, integrada por fuerzas creativas heterogéneas, en las que afros y nativos juegan papel central, que reconoce la extraordinaria diversidad de su cultura, y que denuncia de manera brillante los mecanismos de imposición de una historia y unos valores culturales 
colonialistas. En la tercera parte incluimos artículos y ensayos publicados después de 1965 en publicaciones diferentes a Letras nacionales, en los cuales discute también los temas antes señalados.

\section{En la defensa de lo nuestro}

Tenía apenas 22 años cuando Manuel escribió una columna en el periódico cartagenero Diario de la Costa, titulada Genio y figura. Para ser más exactos el 1 de marzo de $1942^{27}$. En ella, y años antes de que se encontrara con García Márquez en Cartagena, es posible encontrar ya, en la agilidad y precisión de las palabras, y en la modernidad de su estilo literario, al escritor en formación. Al referirse a nuestro modo de hablar costeño, dice que "hasta nuestros prohombres se expresan tan rápido que simulan la persecución encarnizada de una palabra tras la otra".

En esta pequeña nota periodística, escrita desde Bogotá, se insinúa desde muy temprano, su mirada de antropólogo que quiere comprender la geografía fragmentada de Colombia, lo mismo que su pasión por el folclor local. Cuando nadie hablaba de ello, Zapata escribió entusiasta que ha:

tenido noticias a quemarropa de que la famosa casa R. C. A. Victor ha grabado una serie de discos con la orquesta A No 1, de música bolivarense. ¡Hasta cuando iba a permanecer ignorado nuestro folclore musical que se extiende más allá del pentagrama!... Esa música que es el fiel espejo de nuestra alma debe ser conocida por nuestras jóvenes y hermanas naciones. Sus inspiradísimos compositores debieran disfrutar del apoyo oficial, siquiera de los honores que merecen. Ahí están musicalmente dispuestos a brindarnos composiciones Lucho Bermúdez, Santos Pérez, Planeta Pitalúa, Joaquín Marrugo y tantos otros. Pero ¡ah! Indolencia.

Cinco años más tarde, en mayo de 1947, inicia sus colaboraciones con la revista Cromos, con una joya del periodismo cultural titulada El Porro conquista Bogotá ${ }^{28}$. Anticipándose dos décadas por lo menos al surgimiento de los estudios culturales en el mundo, y por lo menos medio siglo a su divulgación en Colombia, Manuel escribe una obrita maestra, en la cual mezcla con destreza de artesano la historia, el conocimiento antropológico y la sociología urbana para el estudio de una forma específica de la cultura popular. Y más allá del simple análisis de sus formas musicales es capaz de intuir el papel del porro en la formación de la nación, en un pueblo tradicionalmente fragmentado, de mostrar con

\footnotetext{
${ }^{27}$ Manuel Zapata Olivella, Genio y Figura, Cartagena, Diario de la Costa, Marzo 1, 1942, p 12

${ }^{28}$ Manuel Zapata Olivella, "El porro conquista Bogotá”, Bogotá, Cromos, Vol. LXIII, Nº1582, Mayo de 1947, p. 8-9,53, 56.
}

Poligramas 35, primer semestre 2011, ISSN 0120-4130. 
claridad absoluta su asentamiento en la capital como el producto de una larga batalla contra la ignorancia y los prejuicios aristocráticos y raciales, de examinar sus orígenes históricos, su savia popular, producto del encuentro múltiple de indígenas y negros en pueblos apartados, su renacer en las calles de Cartagena en manos de músicos talentosos venidos de la provincia y su penoso ascenso a las cimas andinas de la mano de la migración de los costeños a la capital. Y todo esto cincuenta años antes de que Peter Wade escribiera su juicioso libro sobre la música colombiana.

No resisto la tentación de copiar abajo el primer párrafo de este magnífico artículo, para animar a usted lector a que se siente a estudiarlo:

Aun cuando los sociólogos quieran ignorarlo, el porro como rasgo protuberante de la migración mulata hacia la capital, tiene una gran significación. Ha contribuido al enriquecimiento de nuestro folklore, amansándolo y dándole contenido más unitario, más nacional. También juega un gran papel en la afluencia de músicos, turistas y en la movilización de no pocos capitales que aprovechan el snobismo para transformar la melancolía indígena de esta señora de las Brumas. Bogotá ha despertado al oír del tamborileo de los bongoses, del aullido de las maracas y el verso pícaro, desnudo de rubores, de la "puya" y el "vallenato" costeños. El Caribe deja escuchar sus cantares impregnados de algarabía africana en los picachos andinos. No pocos son los rasgos que acentúan en el capitalino, como productos del mestizaje de los glóbulos mulatos disociándose cual pincelada alegre en la acuarela gris del viejo santafereño ${ }^{29}$

Son abundantes los artículos de Manuel publicados entre 1940 y 1965, en periódicos y revistas cuyo tema central es el folclor colombiano. Todos giran alrededor del mismo sentimiento: su deseo ferviente de enaltecer su extraordinario valor artístico-cultural, y su propósito didáctico de enseñar sus contenidos a un país cuya historia y geografía lo había predispuesto al aislamiento de sus regiones, a la ignorancia y el recelo de unos contra otros. Hoy, cuando los jets, los carros que transitan a 140 kilómetros por hora en amplias carreteras y las imágenes diarias de la televisión permiten el encuentro diario de costeños y andinos, nos cuesta trabajo imaginarnos el país que era hace apenas 60 años. Cuan aburridos y exóticos nos parecía una pareja de Boyacenses bailando un bambuco, y cuan risible era para los cachacos ver a unos negros costeños danzando un mapalé.

\footnotetext{
${ }^{29}$ Manuel Zapata Olivella, Ibíd., p. 8.
} 
Sin embargo, y pese a esa evidente fractura de la geografía nacional, dos cosas intenta Manuel Zapata en sus escritos de esta época, claramente perceptibles en sus notas sobre la cumbia y en sus ensayos cortos sobre el folclore colombiano: la primera, identificar los orígenes étnicos y raciales de esas manifestaciones artísticas que comienzan a confluir en la capital, llevadas por los migrantes pueblerinos, de ahí su clara insistencia en la necesidad de estudiar los orígenes africanos e indígenas de muchas de esas expresiones del espíritu nacional. La segunda, mostrar que todas esas músicas regionales, aparentemente extrañas las unas de las otras, tienen un aire que las emparenta, cuya raíz se encuentra en el trasegar de negros e indígenas, zambos y mestizos por el territorio patrio. El papel de los bogas, navegantes de los ríos, no es nada despreciable, tal y cual como insinúa Zapata, en la dispersión de sones y bailes.

En algunas de estas notas resaltará el otro papel admirable de Manuel, entre los muchos que jugó: el de divulgador feliz de ese arte popular sobre el que estudiaba y teorizaba continuamente. En varios de esos pequeños escritos, sobre todo en los publicados en la revista Vida, el lector se encontrará con las narraciones que hace de las primeras giras que organizó con intérpretes del Vallenato y de la Gaita. Leerá maravillosas anécdotas sobre estos juglares legendarios $\mathrm{y}$, sin duda, se encontrará con páginas preciosas, de valor invaluable para la historia nacional, a secas. Es decir, para la historia real de la nación, que apenas se está contando en toda su riqueza y esplendor. Recomiendo en especial esas dos maravillas, que titula: Los gaiteros de San Jacinto ${ }^{30}$ y Los acordeoneros de Valledupar ${ }^{31}$. Pero, además del folclor, otras preocupaciones no menos importantes están registradas en las notas que recogemos en este primer aparte. En esos mismos años de 1947 y 1948 Manuel escribirá una serie de colaboraciones para la revista Sábado en las que recogerá sus impresiones sobre el New York de los pobres. La primera lleva por título "Miserias de New York" $^{, 32}$ y es publicada el 6 de septiembre de 1947. Con una pluma muy ágil y un uso diestro del español describe a sus 25 años el submundo que habitan los seres destruidos por el ritmo demoniaco de la gran ciudad. Lo que lo atrae no es, por supuesto, el New York de los turistas, sino ese otro que es la cara oculta de la tarjeta postal. Además del estudio de las

\footnotetext{
${ }^{30}$ Manuel Zapata Olivella, "Del folklore: Los gaiteros de San Jacinto” Bogotá, Vida, № 57, Segunda Época, Compañía Colombiana de Seguros, Junio - Julio de 1953. p 44 - 47

${ }^{31}$ Manuel Zapata Olivella, "Personajes populares: los acordeoneros de Valledupar”, Bogotá, Vida, N 58, Segunda Época, Compañía Colombiana de Seguros, Agosto - Septiembre de 1953. p 24 - 27.

${ }^{32}$ Miserias de New York”. Bogotá, Revista Sábado, Septiembre 6 de 1947, p13-15 
realidades urbanas, es evidente en este ensayo la intencionalidad política. La clara disposición a mostrar las lacras del capitalismo en todo su esplendor. De talante impresionista, desfilan por estas páginas una galería de personajes fantasmales, alrededor de una plaza de mercado, poblada de borrachos, drogadictos y veteranos vencidos por una realidad peor que la guerra.

Más adelante, en 1948, publicará "Harlem Olvidado"33. Aquí se ocupará de la vida del legendario barrio de los negros de New York, migrantes del sur muchos de ellos. Narrará su decadencia y su transformación de centro de la intelectualidad negra y del movimiento jazzístico, en su edad de oro, a epicentro de la lucha contra la discriminación racial, durante su posterior decadencia económica. Él es testigo excepcional de esa transición y del nacimiento de ese movimiento antirracista que se convertirá luego en una gran revolución por los derechos civiles de los afrodescendientes. En el mismo año escribe otra crónica en Sábado, que hemos considerado de interés y hemos incluido en esta compilación. Se trata de La raza negra y el arte ${ }^{34}$. Otra vez sobre New York, ahora para el elogio del gran artista negro Paul Roberson.

También en marzo del 48 cuenta en la revista Cromos su primera visita al Palenque de San Basilio, acompañado de unos distinguidos extranjeros. Los negros palenqueros ${ }^{35}$ es el título del relato. Valioso, sobre todo, porque contiene las primeras percepciones de Manuel Zapata sobre la extraordinaria riqueza cultural y sociológica del pequeño poblado de los descendientes de los cimarrones.

\section{Letras nacionales: 1965}

Cuando Manuel se lanzó a la aventura de fundar una revista literaria en 1965, había publicado ya 6 novelas, y se había ganado el segundo puesto en el concurso nacional de Esso, en el que García Márquez obtuvo el primer lugar con La mala hora. Había conocido buena parte del mundo, organizado el primer congreso de la cultura colombiana y participado en la creación de la Junta Nacional de Folclor, además de haber ideado y promovido decenas de empresas culturales a favor de los artistas populares. Su muy buena novela, En Chima nace un santo, le había merecido comentarios elogiosos de varios de los

\footnotetext{
${ }^{33}$ Manuel Zapata Olivella, "Harlem olvidado". Bogotá, Sábado, Diciembre 25 de 1948. p 6, 14

${ }^{34}$ Manuel Zapata Olivella, "La raza negra y el arte”. Bogotá, Sábado, Noviembre 27 de 1948, p 7, 15.

${ }^{35}$ Manuel Zapata Olivella, "Los negros Palenqueros”. Bogotá, Cromos, Vol. LXV, N 1622, Marzo 13 1948, p 30-31,4546.
}

Poligramas 35, primer semestre 2011, ISSN 0120-4130. 
críticos más severos y lo habían consagrado como uno de nuestros mejores novelistas. Tenía por lo tanto toda la autoridad, el conocimiento y la experiencia para intentar lo que se proponía, con indudable éxito: hacer de la revista el centro de su batalla por la joven literatura colombiana y por lo que él llamaría la defensa del nacionalismo literario.

Pero, además, Manuel había escrito, antes de fundar Letras nacionales, algunos ensayos en los que exponía ya sus ideas cardinales sobre la literatura, particularmente en dos de ellos que vienen en esta compilación. Me refiero a El tuerto López y el nacionalismo literario ${ }^{36}$, publicado en 1962 en el Boletín Cultural y Bibliográfico del Banco de la República, y La nueva novela hispanoamericana ante Europa $^{37}$, de 1964, en el mismo boletín. En el primero intenta, quizás por primera vez resumir el rasgo esencial de lo que entiende por nacionalismo literario, a propósito de la obra del célebre poeta cartagenero.

"La poesía del "tuerto" - dice- es un buen ejemplo de nacionalismo literario. No faltará quien se diga a sí mismo que hablar de nacionalismo literario en la poesía del "tuerto", es buscarle tres patas al gato. Esto sería cierto si por nacionalismo literario queremos significar una de las tantas formas de "ismo" que pululan en nuestros días. Pero no si con estas palabras deseamos aludir al amor por lo propio, la autenticidad y la fidelidad de los temas terrígenos. Y el cariño por la patria -grande y pequeña- fue en el poeta una obsesión."

En el segundo, La nueva novela hispanoamericana ante Europa, hace una de las exposiciones más lúcidas y equilibradas de este concepto, que será, un año más tarde cuando funde la revista, guía y caballo de batalla en Letras nacionales. Ahí deja claro dos elementos constitutivos de su modo de pensar la literatura colombiana: su convicción universalista y anti parroquial, en primer lugar. Es decir, la clara comprensión que había en él y en el resto de escritores costeños, que venían trabajando desde finales de los años cuarenta para fundar la literatura moderna en nuestro país, de que sólo mediante la asimilación de las nuevas visiones, procedimientos narrativos y técnicas de la novela contemporánea, encarnadas en las obras de Kafka, Proust, Joyce y Faulkner, se podría

\footnotetext{
${ }^{36}$ Manuel Zapata Olivella, El Tuerto López y el nacionalismo literario". Bogotá, Boletín Cultural y Bibliográfico. Vol. V № 9. Banco de la República. 1962. p 1183 - 1185.

${ }^{37}$ Manuel Zapata Olivella, "La nueva novela hispanoamericana ante Europa". Bogotá, Boletín Cultural y Bibliográfico. Vol. VIII No 1. Banco de la República. 1964. p 31 - 36.
} 
explorar y exponer eficazmente el alma atormentada por una historia de guerras infinitas de los colombianos.

Hay otra crítica muy común - dice- que entre nosotros suele hacerse a García Márquez y a Cepeda Samudio. Se les condena por el aprovechamiento que hacen de la técnica faulkneriana para tratar argumentos colombianos. Se llega hasta decir que su relato infunde cierto carácter anglosajón a nuestros mestizos. No compartimos esas críticas. Creemos que el camino seguido por ellos, el mismo de Carpentier cuando imita a Proust, es el apropiado si se quiere evolucionar en la creación novelística. Lo malo sería, y esto es lo que reclaman los críticos europeos o europeizados, que cayeran en aquella posición de que nos habla Unamuno, dejar de describir lo que tienen ante los ojos para descubrirles Europa a los europeos.

Y su postura anti demagógica, pese a que lo atacan de lo contrario, en segundo lugar. Su amor incondicional por las expresiones del arte popular no obsta para que no hable de la “encrucijada en la que nos encontramos todos los escritores de aquellos países históricamente rezagados en el dominio de la técnica, de la civilización y en bienestar social contemporáneo." La encrucijada de ambicionar el dominio de las formas modernas, con todas sus complejidades, al mismo tiempo que debían escribir para un público poco educado. Por eso, al referirse al escritor latinoamericano, no dudó en decir que "la masa analfabeta es un lastre para su labor creadora. El incremento de la cultura en general es una liberación de sus formas expresivas."

La década de 1958-1968 es uno de los momentos de más intensa reflexión crítica sobre el sentido de la nación colombiana, sobre su historia y cultura. Es al mismo tiempo un período de optimismos políticos desenfrenados y de hondos pesimismos. Muchas cosas decisivas para la historia nacional ocurren en esos años. Se monta la dictadura bipartidista del Frente Nacional, con la secuela de sus gravísimas exclusiones, la violencia no amaina, sino que por el contrario da nacimiento a dos de los grupos guerrilleros que marcaron el acontecer de los últimos 50 años: las Farc y el ELN. El nadaísmo y el hipismo local expresan el desaliento de sectores amplios de la juventud, mientras en universidades como la Nacional, las posturas políticas de izquierda de profesores y estudiantes alientan en nuestro medio el movimiento antimperialista internacional. Es época de grandes huelgas obreras y estudiantiles, al mismo tiempo que el padre Camilo Torres toma la decisión radical de ingresar a las guerrillas revolucionarias de aquel momento, llevado por sus convicciones pero también por el miedo a que lo mataran en plena séptima. 
Manuel era un hombre de izquierda desde sus primeros escritos de los años cuarenta, y nada ni nadie lo había apartado un milímetro de sus convicciones políticas fundamentales en enero de 1965, año en el que fundó Letras nacionales, con el apoyo entusiasta de otros intelectuales como Manuel Mejía Vallejo y Carlos José Reyes. De modo que en el ambiente de intensas disputas ideológicas de los sesenta, Manuel tomó partido como siempre había tomado y tomaría. Y Letras nacionales, por lo mismo, expresaría desde su primer número, el 0, una posición política clara, sin ambigüedades, al estilo de su inspirador. En su editorial $^{38}$ de presentación del gran proyecto literario, que sería la revista dice:

"Hay una literatura colombiana. Teatro, poesía, novela, cuento, ensayo. Letras nacionales será una revista para mostrarla, juzgarla y exaltarla. Tomamos una responsabilidad que nadie ha querido asumir hasta ahora en nuestro país. Unos miran avergonzados cuanto se escribe. Otros no alcanzan a comprender el significado nacional que implica la publicación de un libro. Hay quienes piensan que el acto de escribir debe estar condicionado a la realización de una obra universal.

La literatura es un fenómeno histórico y social. Aparece como una necesidad. Es el haber de las experiencias culturales que puede guardarse en la memoria o en el papel escrito. Pero en los conflictos políticos y económicos contemporáneos, hay quienes, defendiendo intereses particulares, niegan la existencia de una literatura nacional en pueblos que fueron o son oprimidos. Los teóricos y críticos de los subyugadores hablan de "inmadurez cultural", "primitivismo", "lastre racial", "incapacidad", "recursos incipientes" y de otras necesidades. Pretenden con esta jerga justificar en una u otra forma los privilegios. A despecho de sus propias aseveraciones, se apresuran a destruir la literatura nativa tradiciones, folclore, archivos, idiomas- y cuando les es imposible incinerar, empecinadamente niegan los valores objetivos. En el primer caso, aniquilada y asfixiada (colonias africanas), se asume una actitud paternalista y se hace alarde de crearla y desarrollarla dentro de ciertos cánones. Si hay un mestizaje cultural que no se puede ocultar (América Latina), se argumenta falta de aculturación. En ambos casos pretenden crear complejos de incapacidad a fin de que se deje a los colonizadores el derecho de juzgar lo bueno y lo malo en el proceso cultural.

\footnotetext{
${ }^{38}$ Manuel Zapata Olivella, “Esto Somos, Esto Defendemos”. Letras Nacionales, Nº, Bogotá, 1965. p 3 - 5.
} 
El hecho literario como fenómeno real tiene sus propias leyes; evoluciona de acuerdo a las críticas. Esta realidad arranca de la existencia de una actividad creadora que es patrimonio del pueblo y no de quienes lo juzgan. Aquí surge la alienación. La literatura nace cotidianamente en la conversación del boga, en la letra deforme del niño, en la copla del tiplero, en la prédica del cura. La narrativa, el cuento, la expresión, al comunicar e identificar el pensamiento de unos y otros, trae al idioma la novela y la literatura. La universidad, el filólogo, el novelista solo dan forma académica o artística a la creación anónima que se nutre de la vida, de la existencia del conglomerado social. Habrá pues tantas literaturas como contingentes sociales se encuentren identificados en una misma habla, en una misma unidad psicológica y cultural. Los límites de esta nacionalidad variaran de acuerdo con ciertos intereses políticos pero más allá de ellos estará uno sólido y lógico: la identificación cultural. Muy otro es el fenómeno de la calidad literaria. Puede discutirse sobre la mala o la buena literatura. De su limitación regional o de su alcance regional. Lo que no admite o no debiera admitir discusión es la existencia de la literatura de un pueblo dado.

Dentro de esta posición, Letras nacionales se propone presentar la obra de escritores colombianos con un espíritu beligerante, polémico, sea cual fuere su orientación literaria y política, siempre que sea eminentemente afirmativa de lo nacional. Nuestras páginas no estarán al servicio de quienes desean ostentar un culturalismo sin fronteras. Tampoco de aquellos que se olvidan del país cuando escriben. Pero esta actitud no implica un rechazo al aprovechamiento de las experiencias acumuladas por la cultura universal. Somos parte de América, del mundo, recibimos, damos.

En el siguiente número, el 1, responde a las críticas de Hernando Téllez y de otros comentaristas del quehacer literario, con otra especie de manifiesto que titula Letras nacionales responde a 8 preguntas en torno al Nacionalismo Literario ${ }^{39}$. Documento clave, entre otros, para validar nuestra afirmación de que Manuel Zapata expresa en Colombia, primero que nadie, la crítica al colonialismo cultural, además de que lo muestra como miembro importante, en todo caso, de ese conjunto de intelectuales caribeños y latinoamericanos que en los años sesenta y setenta construyeron el pensamiento poscolonial más rico en intuiciones, metáforas y reflexiones sobre nuestros destinos nacionales. Llamo

\footnotetext{
${ }^{39}$ Manuel Zapata, "Responde a 8 preguntas en torno al nacionalismo literario”. Letras Nacionales, Bogotá, No. 1, MarzoAbril 1965, p $9-15$.
}

Poligramas 35, primer semestre 2011, ISSN 0120-4130. 
la atención a la exposición temprana de su visión poscolonial de la historia, similar en muchos aspectos a como la formulará años después Edouard Glissant. Veamos un aparte:

Habitualmente se entiende entre nosotros por literatura nacional el proceso de asimilación de la foránea. Cuentan solo las vicisitudes de las ideas ajenas en nuestro medio. De ahí que se pretenda dividir la historia de la literatura nacional relacionada con aquellas. Los términos usuales de clasificación son harto conocidos: Descubrimiento, Conquista, Colonia, Independencia, Universalización. Tal parece que importara poco el fenómeno nacional ya que este, según ese razonar, no tiene existencia propia, sino conciencia receptiva, literatura parasitaria. La árida cara de un satélite que refracta luz prestada"

Ya es tiempo de que al hablar del híbrido no solo se analice lo que recibimos de la literatura colonizadora sino también la respuesta de la colonizada. ${ }^{40}$

En ese párrafo está admirablemente expresado lo que Manuel de una forma u otra venía diciendo años atrás. Varios puntos me parecen clave de destacar: en primer lugar, al igual que lo hará Glissant en 1976, Manuel expresa su inconformidad con una visión de nuestra historia que sigue una nomenclatura colonial. Es decir una clasificación que se apoya en los eventos que definen la presencia del colonizador, pero no la historia propia del colonizado. En segundo lugar, convoca la imprescindible presencia del colonizado y el registro de su historia de resistencia en la narración oral o en los archivos. Y en tercer lugar, propone que esa historia encuentre su eje en lo nuestro, en el estudio de nuestra condición híbrida.

En el editorial del número 2 de mayo-junio de $1965^{41}$ insiste en la defensa del nacionalismo literario, por el que se le acusa de una posición chovinista y de estrechez ideológica. En un par de párrafos de admirable precisión expone nuevamente el sentido universal de su concepto, enriquecido por una perspectiva poscolonial que denuncia la hegemonía excluyente y esa sí chovinista del pensamiento dominante de Occidente, para incluir ahora dentro de lo universal las culturas marginadas de los pueblos explotados de América, Asia y África.

Nuestro nacionalismo -afirma- no es ciego ni estrecho. Tenemos conciencia exacta de los valores regionales y universales, lo que no significa que nos sintamos inferiores a lo foráneo. Somos universales por el solo hecho de existir, de representar la suma de las culturas de la humanidad (América, Asia, África y Europa). Con esta clarividencia sobran

\footnotetext{
${ }^{40}$ Ibid. P. 10

${ }^{41}$ Manuel Zapata Olivella, “Chauvinismo literario y complejo nacionalista”. Letras Nacionales, N², Bogotá, Mayo-Junio 1965. p $8-10$.
} 
los temores de que pretendamos autoimputarnos del mundo, como subjetivamente lo han venido haciendo quienes creen que no representamos nada en la literatura universal.

Se hace necesario, sin embargo, luchar contra los reflejos condicionados heredados del viejo coloniaje que sepultó la cultura indígena, subestimó a la negra y autodiscriminó a la mestiza. De ahí arranca ese gesto peyorativo ante lo criollo y la alucinación por todo lo ajeno, aun cuando muchas veces el brillo de este sea del mismo quilate de las cuentas de vidrio que nos cambiaban por pectorales de oro puro.

Letras nacionales iría más allá de la exposición conceptual y de las batallas alrededor del Nacionalismo Literario. En los editoriales de Manuel que reproducimos en este libro otros cuatro aspectos se convierten en centros alrededor de los cuales elabora su crítica incansable contra el predominio de un pensamiento alienado, que niega la existencia y el valor de la cultura del otro sometido y marginado de la vida nacional, y, sobre todo, de las esferas intelectuales.

El primero de ellos está consagrado en su extraordinaria polémica contra la ausencia de una crítica literaria y artística seria. En el editorial del número 3 hace de este, el tema central, en particular en el aparte que titula El escapismo en la novela ${ }^{42}$. Cuestiona el papel de los críticos, tanto de aquellos que se aferran a las viejas tradiciones para impugnar los nuevos campos que se abren en la novelística moderna, como de aquellos que desprecian la literatura colombiana sin conocerla. En uno de sus párrafos reclama que en nuestro medio se pretende criticar sin tomarse el trabajo de estudiar las condiciones que determinan la novela y al novelista. Su interés es comparar el producto de las observaciones subjetivas de lecturas foráneas sin consultar la realidad nacional. Así los vemos reclamar - violando la libertad creadora que en otro sentido reclaman para su crítica - que se haga una novela "burguesa" de "burgo" en un país eminentemente campesino. Quieren ellos que el escritor se autoexilie de sus sentimientos, de sus efectos, de su comarca, para rivalizar en la problemática y los autores de otras latitudes. Pero su inconsecuencia, para no llamarlo prejuicios va aún más allá cuando ni siquiera se acercan al estudio juicioso de la literatura nacional antes de pensar en sus reservas. Precisamente porque nuestros novelistas en su gran mayoría saben sobre que temática escriben, han proyectado en sus obras la dualidad propia de nuestro país donde el burgo ha dejado de ser campo. La lista de las novelas con

\footnotetext{
${ }^{42}$ Manuel Zapata, "El escapismo en la novela”. Letras Nacionales, №3, Bogotá, Júlio-Agosto 1965. p 14 - 19. 
desarrollo en la ciudad es interminable. ¿Entonces porque se reclama a nuestros autores que dejen de escribir sobre la provincia y se concentren en la ciudad? Primero: no se han leído esas novelas o lo que es peor, se ignora que existan. Segundo: esgrimiendo ese falso argumento, se pretende dar base a la necesidad de una novelística psicológica, individualista, subjetiva, que plantea los problemas del hombre desraizado, sin más horizonte que el cosmopolitismo vacuo. ${ }^{43}$

En el número 12 regresa a la discusión sobre el papel de los críticos, con un editorial que titula, La crítica, un compromiso nacional ${ }^{44}$, en el que insiste en su punto de vista: es decir, en la tesis de que la valoración de una obra no puede separar al autor de su entorno geográfico, social y cultural, y en su certidumbre de que esa gran literatura que está madurando en América latina de la mano de escritores como Vargas Llosa o García Márquez es el producto de esa mirada completa y profunda de sus raíces y de la búsqueda y aprovechamiento de los materiales que la vida misma de esas gentes anónimas les ofrece. Manuel Zapata no se cansa de exponer en este y en muchos de los números que siguen su certidumbre de que el punto de quiebre que explica el vigor y la universalidad de esta nueva literatura latinoamericana está esencialmente en esa incorporación de las nuevas narrativas cosmopolitas ahora al trabajo serio y sistemático de la realidad de los pueblos latinoamericanos con una mirada que se despoja de su visión alienada para recobrar su autenticidad.

El segundo de los aspectos que define el trabajo editorial de Manuel Zapata en Letras nacionales tiene que ver con su defensa del arte y de la cultura de los de abajo, que él prefiere llamar muy a menudo analfabetos y semianalfabetos. Inseparable de sus postulados alrededor del nacionalismo literario es su contagioso entusiasmo y valoración del arte y la cultura popular, que, como hemos visto más arriba, es motivo central de sus escritos y de su actividad de gestor cultural. Al explicar los objetivos de la Fundación Colombiana de Investigaciones Folclóricas, creada por él en 1973, dice: "Sus objetivos se orientan primordialmente a la investigación de una vasta área de la cultura colombiana, por lo general fuera del interés de las entidades académicas del país: la creatividad de las capas

\footnotetext{
${ }^{43}$ Ibid. PP. 17-18

${ }^{44}$ Manuel Zapata Olivella. "La crítica un compromiso nacional”. Letras Nacionales, №14, Bogotá, Mayo-Junio 1967. p $12-15$.
}

Poligramas 35, primer semestre 2011, ISSN 0120-4130. 
analfabetas y semianalfabetas que constituyen más del $80 \%$ de nuestra población." 45 En el número 37 de 1977, publica la ponencia que ha llevado al Simposio Internacional de Literaturas Hispánicas, celebrado en el curso de ese año en la Universidad de Nuevo México. Manuel, con deliberado propósito, la titula: “Características del contexto literario analfabeta y semiletrado de la América latina."46

Después de afirmar que: "gracias al influjo ejercido por esta vertiente analfabeta sobre los más destacados escritores contemporáneos, se debe la feliz circunstancia de que nuestra literatura escrita haya encontrado su propia originalidad en el marco universal”. Agrega:

La importancia de este último gran contexto literario que agrupa más del $80 \%$ de la población latinoamericana, no ha sido justamente valorada en lo que representa como substrato de nuestra literatura escrita, no obstante el reconocimiento que se ha hecho de su permanente influjo en las letras latinoamericanas. Las razones de tal soslayamiento están íntimamente relacionadas con el menosprecio que siempre se tuvo de la cultura indígena y sus trabazones mestizas con los aportes africanos. ${ }^{47}$

En este ensayo, finalmente, Manuel emprende la labor de resumir lo que él considera las características de la literatura analfabeta y semiletrada. Leerlas hoy, más de treinta años de haber sido publicadas, permite entender hasta qué punto Manuel venía realizando un esfuerzo hercúleo y casi solitario en la empresa de dotar a los subordinados de su propia voz o, mejor dicho, en la extraordinaria labor de hacerla escuchar.

El tercer aspecto, que estará presente también, no sólo en Letras nacionales, sino a lo largo de su vida en las más variadas revistas y periódicos, es su explícita y honesta denuncia del racismo y la exaltación de lo negro e indígena en la valoración de nuestra cultura. En muchos de los editoriales de su revista encontramos su deseo de precisar las razas que nos conforman, su intensa mezcla biológica y cultural y la centralidad de la cultura y del arte que producen a diario. La crítica abierta y radical al proyecto hegemónico dominante desde la colonia de contenidos racistas y discriminatorios, y la clara conciencia de que la nación es ante todo el producto de esas raíces, del intenso mestizaje de millones de indios, negros y españoles a lo largo de los siglos. Letras nacionales celebró como un gran acontecimiento la realización del Congreso de la Cultura Negra en Cali en agosto de 1977, organizado por

\footnotetext{
${ }^{45}$ Manuel Zapata. Letras Nacionales, Bogotá, No. 42, 1985

${ }^{46}$ Manuel Zapata Olivella. "Dos propuestas: Características del contexto literario analfabeta y semiletrado de la América Latina". Letras Nacionales, $\mathrm{N}^{\circ} 37$. Bogotá, 1977, p 83 - 90.

${ }^{47}$ Ibíd. p. 84.
} 
Manuel Zapata, hasta el punto de editar un número como homenaje a dicho evento, cuyo contenido está conformado por cuentos y poesías de escritores afros del país, la mayoría de ellos, jóvenes y todavía desconocidos.

Finalmente, animaba a Manuel el claro propósito de hacer de Letras nacionales la casa de los jóvenes escritores. Con un espíritu solidario, que era el producto de sus convicciones más profundas, abría las páginas de la revista -y su sala de tertulia- a aquellos muchachos recién llegados de la provincia a la capital, medio perdidos en la gran ciudad y en busca de un editor generoso que diera a conocer sus primeros cuentos y poemas. En una crónica sobre Zapata Olivella, con ocasión de su muerte, Óscar Collazos evoca aquellos años:

Conocí a Manuel Zapata Olivella a finales de 1965. Empezaba su aventura de editor de la revista Letras nacionales, que mantuvo con tenacidad y gracias al empuje y la lealtad de Rosa Bosch, su esposa catalana, a quien había conocido en su vagamundeo por Europa, tal vez de regreso de la Unión Soviética, adonde había viajado con el grupo de danzas que había fundado y dirigía su hermana Delia.

Letras nacionales fue una revista clave para una generación de escritores que empezábamos a publicar por esas fechas: Germán Espinosa, Policarpo Varón, Roberto Burgos Cantor, Ricardo Cano Gaviria, Luis Fayad, Umberto Valverde, Darío Ruiz Gómez, Fanny Buitrago y Alberto Duque López, entre otros...

... No hay escritor que no recuerde la generosidad de Manuel, su infatigable actividad... ${ }^{48}$

Además de los editoriales, hemos querido incluir en este libro dos de los ensayos publicados por Manuel Zapata en la revista, como una muestra de lo que el entendía por una crítica literaria, que situaba al autor y su obra en su contexto socio-cultural. El primero, sobre Faulkner permite mirar cuan familiarizado estaba ya en los años sesenta con la obra del gran escritor norteamericano, que tanto influyó en los escritores de su generación ${ }^{49}$. Y el segundo, sobre María, es, conjuntamente con el escrito por Rogelio Velásquez en 1957, uno de los ensayos más penetrantes sobre la obra de Issacs, particularmente en el análisis de

\footnotetext{
${ }^{48}$ Oscar Collazos, Manuel Zapata Olivella, Noventaynueve, Cartagena, 2005.

${ }^{49}$ Manuel Zapata Olivella. "Faulkner y el costumbrismo". Letras Nacionales, N`31, Bogotá, Agosto-Septiembre, 1976. p 15 -21.
}

Poligramas 35, primer semestre 2011, ISSN 0120-4130. 
la presencia negra en la obra. Y a diferencia del antropólogo chocoano, Zapata se detiene más en el estudio estilístico del realismo y del tipo de romanticismo de María ${ }^{50}$.

Letras nacionales fue, como muchas de su época, una revista intermitente, cuyas páginas se cerraban durante largos períodos, casi siempre por razones de orden económico. Manuel se quedaba sin dinero y sin patrocinios, y había entonces que esperar a mejores épocas. Así y todo, reapareció en varias ocasiones, a lo largo de 20 años, y circularon 42 números. No me cabe la menor duda que este proyecto editorial ambicioso enriqueció y ayudó a transformar la vida cultural y artística de la Colombia aún conservadora y tradicional de los años sesenta y setenta, como todo aquello que produjo la mente febril y extraordinariamente creativa de este gran escritor y divulgador de nuestra cultura popular.

\section{Raza e Identidad: 1966-2000}

Los años posteriores a Letras nacionales fueron, además de muy fructíferos en materia de novelas y relatos, un intenso período de maduración de sus ideas sobre el papel de las razas y los procesos culturales de formación de una identidad en los pueblos de América latina, y de manera particular en Colombia. Muchas de sus conclusiones quedaron registradas en libros como El hombre colombiano, ¡Levántate mulato! Por mi raza hablará el espíritu, Nuestra Voz. Aportes del habla popular latinoamericana al idioma español y La rebelión de los genes, El mestizaje americano en la sociedad futura. Pero antes de convertirse en libros, sus tesis fueron expuestas en una variedad de artículos publicados en distintas revistas y periódicos nacionales y extranjeros, una muestra de los cuales incluimos en este libro.

La década de los sesenta del pasado siglo no sólo se distinguió por las transformaciones socio-culturales y políticas al interior de la nación, sino, y sobre todo, por las que tuvieron lugar en el mundo. El reciente triunfo de la revolución cubana y los movimientos de liberación nacional de los países africanos y caribeños trajeron consigo un robustecimiento de los movimientos y de las ideologías nacionalistas y un relativo auge de las luchas anticoloniales y antiimperialistas. En particular, los años sesenta marcaron, ante todo, la consolidación del movimiento mundial contra el racismo, el inicio de la revolución por los derechos civiles en los Estados Unidos y del repudio internacional del apartheid. Manuel

\footnotetext{
${ }^{50}$ Manuel Zapata Olivella. "María. Testimonio vigente del romanticismo americano”. Letras Nacionales, $\mathrm{N}^{\circ} 14$, Bogotá, Mayo-Junio 1967. p 15 - 44. 
Zapata fue, y esto es muy importante para entender su obra, un protagonista de primera línea en la gran batalla mundial por los derechos de los pueblos oprimidos y dominados por el poder de una ideología profundamente racista. Y lo fue como activista que organizaba marchas, seminarios y congresos internacionales, pero principalmente como escritor radicalmente comprometido con dicha causa.

No es este el lugar para un análisis más detenido de la evolución de las ideas de Manuel Zapata en torno al papel de las razas en la historia de la nación, pero, sin duda, podemos avanzar algunos de los elementos constitutivos de este proceso. Lo que sí es interesante es observar el valor de sus intuiciones, muchas de ellas expuestas como tales, es decir sin el diseño metodológico de las investigaciones que se precian de científicas. No está de más decir que una parte importante del más rico y penetrante pensamiento Caribe está formulado en ensayos que acuden más a la metáfora y la intuición que a las argumentaciones basadas en aparatos empíricos, como es el caso de muchos de los escritos de autores como Aimé Césaire y Edouard Glissant.

En 1967 publica El Folklore como afirmación de la nacionalidad. Pequeño escrito en el que, como suele hacerlo con frecuencia, utiliza la palabra folklore para referirse de manera global a esa parte de la cultura de los pueblos oprimidos que él atribuye a la creación de los sectores populares y, de manera más concreta, la que elabora el pueblo con los materiales de las culturas nativas, afros, e incluso europeas, en contraposición a aquella que imponen los conquistadores o las élites en el poder. En el uso deliberado de la categoría de "raza" para nombrar a conquistados y conquistadores y para asociar los procesos de diálogo y conflicto cultural a las luchas anticoloniales está uno de los aportes de Manuel al análisis de la historia colombiana en el siglo XX. Y revela, así como en el uso de otros conceptos y visiones, su manera de situarse en una tradición intelectual caribeña -y africana- que toma distancia de una historia colombiana dominada por las realidades propias del mundo andino, renuente hasta ese momento a utilizar las categorías raciales para explicar las dinámicas de opresión, de colonialismo y, sobre todo, para reflexionar en el papel de la cultura.

Ahora bien, hay todavía una cierta ambigüedad en estos primeros intentos por pensar y crear nuevas imágenes acerca de nuestra historia. Su mirada del sujeto diaspórico, es decir del africano que es forzado a abandonar su tierra y a atravesar el Océano Atlántico, se 
mueve bruscamente entre la poderosa imagen que lo revela acompañado sólo de su sombra -su total despojo- y su énfasis en las contribuciones creadoras, de aquello que lo acompaña espiritual e intelectualmente, es decir de su acervo cultural africano. Esta tensión está presente en otro ensayo que publica ese mismo año de 1967 en el Boletín Cultural y Bibliográfico del Banco de la República. Allí describe a los africanos de la travesía esclavista así: "Desnudos y encadenados, fue muy poco o nada lo que pudieron traer consigo. El único objeto material, el único equipaje en este azaroso viaje hacia lo desconocido, fue su sombra." Para más adelante afirmar:

Sin embargo, pese a estas dificultades, los esclavos, impulsados por la necesidad de procurarse viviendas, instrumentos de música, herramientas, armas de cacería, para su propia subsistencia o impelidos por el mismo amo a la confección de útiles para su uso -canoas, tejidos, alimentos, etc.lograron rehacer con elementos americanos muchas formas de su cultura material...Dentro de un relativo aislamiento, lograron conservar ciertos hábitos ceremoniales, alimenticios, comunitarios, etc. La constante que predominó en todo el litoral fue de transculturación con lo indígena y lo hispánico. El mestizaje, con acento negro aparece en los instrumentos musicales, en los bailes, la alimentación, en la pesca, la agricultura y la ganadería. ${ }^{51}$

Igual tensión se siente entre la exaltación de la mezcla de las culturas populares y la creación de un sujeto cultural híbrido y su, a veces, defensa romántica de la pureza o autenticidad de lo nacional, que lo lleva en ocasiones a rechazar, con un cierto tono ingenuo, o quizás heredado de las viejas discusiones marxistas, "la penetración perturbadora de las influencias extrañas a través del cine, la televisión, la radio, los discos, etc., que difunden los modos cosmopolitas de las grandes urbes." 52

Unos años más tarde, en la década de los setenta, Manuel participará activamente en el gran movimiento de las negritudes, liderado por Sangor y Cesaire, y en sus escritos mostrará su profundo conocimiento de la evolución del movimiento de lucha contra el racismo y las bases teóricas en las que se sustentaba en el pensamiento afro-caribeño. Y él mismo, como dijimos antes será no sólo uno de sus difusores en la América latina, sino uno de sus creadores, sólo que menos estudiado.

Con plena conciencia de que el colonialismo se ha estructurado históricamente mediante la racialización de las políticas y los discursos, afirma que "La negritud desbordó el acento

\footnotetext{
${ }^{51}$ Manuel Zapata Olivella, “Aportes materiales y psicoafectivos del negro en el folklore colombiano”, Boletín Cultural y Bibliográfico, Bogotá: Banco de la República, Vol. X, No. 6, 1967, 1385-86.

${ }^{52}$ Manuel Zapata Olivella, "El folklore como afirmación de la nacionalidad”, Página de Cultura, Cali: Instituto Popular de Cultura de Cali, 1967. P. 12.
} 
poético y romántico para convertirse en el ideario político-filosófico de la descolonización." 53

En el XLII Congreso Internacional de Americanistas, Manuel Zapata leerá una conferencia titulada Opresión y explotación del africano en la colonización de América latina. ${ }^{54}$ Armado aquí de un conjunto de lecturas que hace explícitas, y que van de Fernando Ortiz, Eric Williams y Gilberto Freyre a Gonzalo Aguirre Beltrán y Darcy Ribeiro, intenta pensar el problema de la explotación del negro en la colonización de los países latinoamericanos, ya no solamente, como se acostumbraba en aquellos años, desde las estadísticas del comercio esclavo y de su rol en la economía, sino que lo hace ahora desde lo que él llama la creatividad social del negro, y sus contribuciones a la cultura y sociedad de los pueblos latinoamericanos. En uno de sus aspectos más importantes lo que intentaba Manuel era colocar al negro en el centro de la historia misma, de la cual había sido expulsado o puesto en lugares marginales. Por eso, después de intentar una clasificación de la opresión y explotación del negro en América y de las falacias racistas para justificar su explotación, concluirá su conferencia diciendo:

Sin embargo, en la creatividad social, las formas peculiares del negro, así como las del indio y sus descendientes mulatos, zambos y mestizos -mentalidad, hábitos temperamentales, algunos instrumentos y materias primas- sujetas a su vez a patrones tradicionales, enriquecían el producto final. Sólo a través de estos mecanismos intrincados de la transculturación y la aculturación podemos comprender los aportes de los negros e indígenas a la acumulación de riqueza del sistema colonial. La suma de este proceso determinó el carácter del hombre y la cultura latinoamericanos: pensamiento empiromágico, modalidades del cristianismo, bailes, instrumentos musicales, cantos, costumbres, artesanías, etc. Todo intento de minimizar tales aportes a través de un rasero de pureza, orígenes, patrones primigenios, etc., negaría el elemento más importante de la cultura: la creatividad social del hombre. ${ }^{55}$

\footnotetext{
${ }^{53}$ Manuel Zapata Olivella, "Negritud, identidad y mestizaje", Revista de Historia, Bogotá, Vol. 1, No. 2, julio de 1976, p. 45.

${ }^{54}$ Manuel Zapata Olivella, “Opresión y explotación del africano en la colonización de América latina”. Revista Universidad de Medellín, Medellín, Julio-Septiembre, 1976, pp. 89-107.

${ }^{55}$ Ibíd., p. 106.
} 
Y agrega, abriendo un nuevo campo para la investigación en Colombia, todavía por desarrollar, su valiosa intuición acerca del papel de la espiritualidad y religiosidad africana en el porvenir del mundo:

Los mecanismos de la alienación y desalienación del negro, en el contexto cultural de América y del mundo no han sido esclarecidos totalmente. Mientras hay una aquiescencia en admitir el influjo de Grecia en la raíz de nuestra civilización; del racionalismo francés en el pensamiento contemporáneo; de la filosofía alemana en el dominio de la abstracción pura; de la praxis rusa en la revolución marxista mundial, se soslaya el impacto emocional y religioso de África en la civilización contemporánea. ${ }^{56}$

En su conferencia de 1993, Afroamérica, siglo XXI: tecnología e identidad cultural, las anteriores reflexiones, que aparecen de manera temprana en Manuel, acerca del papel relevante de la herencia espiritual africana se centran alrededor del concepto "Muntu", expuesto aquí por primera vez:

En el contexto de la tradición oral, transmitido en su propia lengua o a través de la impuesta por el colonizador, el concepto de "persona" integrado al ámbito de la "familia" y al medio ambiente, expresado en la palabra "muntu" de los bantú, jugó indudablemente el papel de cohesionador de los pueblos dispersos en América. Este término es intraducible a los idiomas extraños al África, porque su semántica está estrechamente ligada a un modo peculiar de sus culturas. El "muntu" concibe la familia como la suma de los difuntos (ancestros) y los vivos, unidos por las palabras a los animales, a los árboles, a los minerales (tierra, agua, fuego, estrellas) y a las herramientas, en un nudo indisoluble. Esta es la concepción de la humanidad que los pueblos más explotados del mundo, los africanos, devuelven a sus colonizadores europeos sin amarguras ni resentimientos. Una filosofía vital de amor, alegría y paz entre los hombres y el mundo que los nutre. ${ }^{57}$

No me interesa ahora discutir la validez de este concepto para la comprensión de la experiencia histórica de los pueblos africanos, y, en particular, de su situación presente. Lo que quiero resaltar es lo que es evidente en los ensayos de Manuel Zapata sobre la diáspora, la negritud y la historia de los afroamericanos: su voluntad de romper con los presupuestos

\footnotetext{
${ }^{56}$ Manuel Zapata Olivella, "Negritud, identidad y mestizaje”, Revista de Historia, Bogotá, Vol. 1, No. 2, julio de 1976, p. 47.

${ }^{57}$ Manuel Zapata Olivella, “Afroamérica, siglo XXI: tecnología e identidad cultural”, en Ulloa Astrid (Comp.)

Contribución africana a la cultura de las Américas. Bogotá: Instituto colombiano de antropología, 1993, pp. 165-175.
} 
teóricos del pensamiento colonialista, y su esfuerzo por reconstruir la propia voz de los afros en América. El Muntu como aporte específico de la religiosidad africana al mundo, es, según Manuel, el principio que debe guiar una forma de ver el mundo alternativa a la construida por los pueblos conquistadores. Basada no en la explotación y la inferiorización de grandes grupos humanos racialmente nombrados, sino en la fraternidad de todos los que se sienten descender de un mismo origen y compartir un mismo destino. Cuando Manuel Zapata habla de la bondad del mestizaje lo hace en este ensayo no para validar la experiencia del encuentro marcado por la violencia y la explotación que distinguió la mezcla de las razas como experiencia colonial, sino para afianzar su convicción profundamente optimista de que la humanidad evitará el peligro de su propia extinción mediante la unidad de los seres humanos, basada en el estímulo y el respeto a la diversidad. Me parece importante insistir en un punto final: la lectura de estos escritos de Manuel sobre el papel de la raza en la historia de la nación pueden resultarnos familiares hoy, pero no era común - para nada- en los años sesenta del pasado siglo poner el acento en el análisis socioracial. No tengo la menor duda de que su temprana presencia en el New York de 1940s, en particular esa noche memorable en la que siendo aún un joven vagamundo conversó con el gran Laston Hughes, su participación protagónica en los congresos internacionales inspirados en los movimientos de la negritud y su familiaridad y camaradería con los grandes pensadores africanos y caribeños, tales como Leopoldo Sangor y Aimé Césaire, debió colocarlo en una situación de privilegio para comprender lo que estaba cambiando en el mundo de mediados del siglo XX. Pero, además, su entusiasmo sin límites y su comprensión cabal de la energía creadora que se desprendía del arte y de la cultura de los analfabetos y semiletrados, estaban, por encima de todo, entroncados en su propia historia individual. En sus vivencias al lado de esa familia extraordinaria de intelectuales negros -su padre filósofo, su hermana folclorista insigne, su hermano poeta, su otro hermano intelectual revolucionario- que padeció a distintos niveles el racismo imperante en la Colombia parroquial de la primera mitad del siglo XX, y en su manera muy particular de navegar hasta el fondo de su alma, en medio de toda clase de tormentas, para llegar a conocer no sólo con la mente sino con el cuerpo mismo, con cada uno de sus nervios y emociones el dolor y la alegría de sus orígenes, sus más recónditas memorias. 